\title{
Woody plant communities in the Philippine teak forest landscape along Verde Island Passage, Batangas, Luzon, Philippines
}

\author{
ANACLETO M. CARINGAL ${ }^{1,2}$, INOCENCIO E. BUOT JR., ${ }^{1,3,4, \boldsymbol{v}}$, ELAINE LOREEN C. VILLANUEVA ${ }^{3}$ \\ ${ }^{1}$ School of Environmental Science and Management, University of the Philippines Los Baňos. College Laguna 4031, Philippines \\ "email: iebuot@up.edu.ph \\ ${ }^{2}$ Program for Tropical Forestry, College of Agriculture and Forestry, Batangas State University-Lobo. Lobo Batangas 4229, Philippines \\ ${ }^{3}$ Institute of Biological Sciences, College of Arts and Sciences, University of the Philippines Los Ban̆os. College Laguna 4031, Philippines \\ ${ }^{4}$ Faculty of Management and Development Studies, University of the Philippines Open University. Los Baňos Laguna, Philippines
}

Manuscript received: 17 December 2018. Revision accepted: 14 October 2019.

\begin{abstract}
Caringal AM, Buot IE Jr, Villanueva ELC. 2019. Woody plant communities in the Philippine teak forest landscape along Verde Island Passage, Batangas, Luzon, Philippines. Biodiversitas 20: 3189-3198. The study described the communities of woody plants in a semi-evergreen tropical forest dominated by endemic Philippine teak (Tectona philippinensis Benth. \& Hook. f, Lamiaceae) and determined the local environmental factors affecting the distribution of dominant woody species across the Philippine teak forest (PTF) landscape. The Philippine teak is a Critically Endangered species according to the International Union for the Conservation of Nature (IUCN). Quantitative dominance analysis of arboreal vegetation data (basal area and relative dominance) from 24 (20m x 20m) sampling plots generated the cluster dendrogram, while Canonical Correspondence Analysis (CCA) was performed for 47 woody species and habitat-environment variables. As a result, four vegetation zones were named: (I) pure stand of Tectona philippinensis, (II) mixed T. philippinensis-Garuga floribunda-Terminalia polyantha, (III) mixed Celtis latifolia-T. philippinensis and (IV) mixed Tamarindus indica-Xylocarpus rumphii. These zones were governed more by physiographic (altitude ) and edaphic influences of predominantly agro-coastal landscapes. The environmental variables were essential in verifying not only the association of dominant tree flora in the local landscape but also provide insight for forest management zoning and the ecological requirements of the tree species for in-situ and ex-situ biodiversity conservation.
\end{abstract}

Keywords: Endemic species, Philippine teak, Tectona philippinensis, Verde Island Passage

\section{INTRODUCTION}

The tropical forests of Southeast Asia is distinct in terms of floristic composition and diversity due to complex biogeography and environmental heterogeneity (Whitmore 1975, 1988; Newbery et al. 1992; Buot and Okitsu 1998; Newbery et al. 1999; Belonias and Aguilar 2004; Buot and Osumi 2011; Heng et al. 2017). Forest vegetation has a subtle response to environmental influences, resulting in variation in species composition and structure, and serve as bio-indicators of landscape productivity and human disturbances (Buot 2007; 2008; Sopsop and Buot 2013; Nguyen et al. 2015; Van and Cochard 2017). Thus, it was always of interest and value to investigate the plant communities in this landscape (Whittaker 1960, 1965; Mueller-Dombois and Ellenberg 1974; Aragones 1991; Villanueva and Buot 2018).

In the Philippines, there is the existence of diverse natural forests known as ecotypes or formation characterized by distinct species composition and structure, which were classified based on the dominant tree elements (Department of Environment and Natural ResourcesUnited Nations Environment Programme, 1997; Baguinon 2000; Malayang 2001; Pulhin 2002). These formations ranged from sea level up to 2,954 $\mathrm{m}$ altitudes and were the focus of ecological classification since the 1900s (Whitford 1909, 1911; Whitmore 1984; Cadiz 1986; Fernando 1988;
Tan and Rojo 1988; Madulid 1994; Fernando et al. 2008). The Philippine teak forest (PTF), however, has not yet been widely studied among the unique ecotypes in the Philippines.

In Batangas Province along the Verde Island Passage, the forest with Philippine teak (Tectona philippinensis Benth. \& Hook. f, Lamiaceae) occurs as fragments across the agro-coastal landscape at low altitudes (05-200 m asl. particularly in the municipalities of Lobo, San Juan, and Taysan and Batangas City where the natural tree populations show spectacular flowering episodes preceding a long summer (Agoo and Oyong 2008; Caringal et al. 2015). Tectona philippinensis was first described by British botanists George Bentham and Joseph D. Hooker (1876) based on the specimens deposited at London's Kew Herbarium which was collected by English naturalist Hugh Cuming (1432) from the shores of Batangas, Luzon. Because of its limited and fragmented distribution, the species is of special interest to phytogeographers in the Malesian Region (Madulid and Agoo 1990). Based on the assessment criteria of the International Union for the Conservation of Nature (IUCN), T. philippinensis has been classified as Critically Endangered (Madulid et al. 2008).

Given the narrow distribution and current conservation status of Tectona philippinensis, it is therefore important to study the ecological aspect of the PTF to provide in-depth and significant information about this unique ecotype in the 
Philippines. As there were fewer local landscape-level studies about the Philippine teak, this study was undertaken to reveal the dominant floristic elements according to plant community patterns of the Philippine teak forest. Using the data gathered from the vegetation surveys in the Philippine teak forest, the researchers used classification analysis (Cluster Analysis) in identifying the plant communities in the study area. Moreover, ordination analysis (Canonical Corresponding Analysis) was also utilized in investigating the influence of the environment and anthropogenic factors on the species distribution in the Philippine teak forests. The results can be used in forest management zoning particularly in locally and nationally important ridge-to-reef biodiversity conservation corridors of Verde Island Passage.

\section{MATERIALS AND METHODS}

\section{Study area}

The vegetation survey was conducted along Batangas Province, particularly in the areas of Batangas City, municipality of Lobo, and Isla Verde (08-321 $\mathrm{m}$ asl, $13^{\circ} 30^{\prime}-13^{\circ} 40^{\prime}$ North latitudes and $121^{\circ} 05^{\prime}-121^{\circ} 15^{\prime}$ East longitudes) in southwestern Luzon, Philippines (Figure 1). Twenty-four (24) $20 \mathrm{~m} \times 20 \mathrm{~m}$ vegetation plots were taken from Isla Verde to the mainland ( $56.48 \mathrm{~km}$ connectivity), which have gentle to undulating, rolling to moderately steep slopes $(0.10$ to $51.99 \%)$. The plots were located for some distances $(58.5 \mathrm{~m}$ to $6225.28 \mathrm{~m})$ along the coastal cliff towards inland ridges and narrow valley facing the sea of Verde Island Passage (Figure 1). The landscape consists of volcanic agglomerates from various ages such as Talahib Andesite (Upper Oligocene-Miocene), Lobo agglomerate
(Pleiocene-Pleistocene) and San Juan Quartz Diorite (Lower Miocene) where the underlying geography is shallow, soft and porous reef limestone (Pleistocene) including bushes of corals, shells, algae structure and recently alluvium formation (Bureau of Soils 1987; Bureau of Mines and Geo-Sciences-Mindoro Resources Limited Gold Philippines Inc 1981; Caringal 2007; Comprehensive Land Use Plan of Lobo, Batangas 2012; Cox 2010; Mindoro Resources Limited 2004). The mean annual precipitation (1980-2016) is $151.89 \mathrm{~mm}$ in Batangas Province (Figure 2). The precipitation in the province reaches is at its highest records in July $(331 \mathrm{~mm})$. Low rainfall (27-32mm) was experienced during summer, January to April. Annual mean temperature (AMT) was $27.36^{\circ} \mathrm{C}$ ranging from $26^{\circ} \mathrm{C}-29^{\circ} \mathrm{C}$ (Figure 2).

\section{Procedures}

Forest vegetation survey

Fieldworks were conducted from October 2016February 2017 and resulted in a total of $24(20 \mathrm{~m} \times 20 \mathrm{~m})$ vegetation plots $(=0.96 \mathrm{ha})$. The sampling locations were identified before successive field surveys of the Tectona philippinensis forests. The plots were purposively selected based on (i) the quality of trees and associated plants and (ii) the presence of human-related disturbances or expansion activities that may affect the forest structure. Six vegetation plots were located in the coastal zone (including 1 island coast), three plots in a narrow inland valley, and 15 plots in inland ridges-all lying apart west to east from north to south directions (Figure 1). Vegetation assessment was done following the techniques of Mueller-Dombois and Ellenberg (1974).

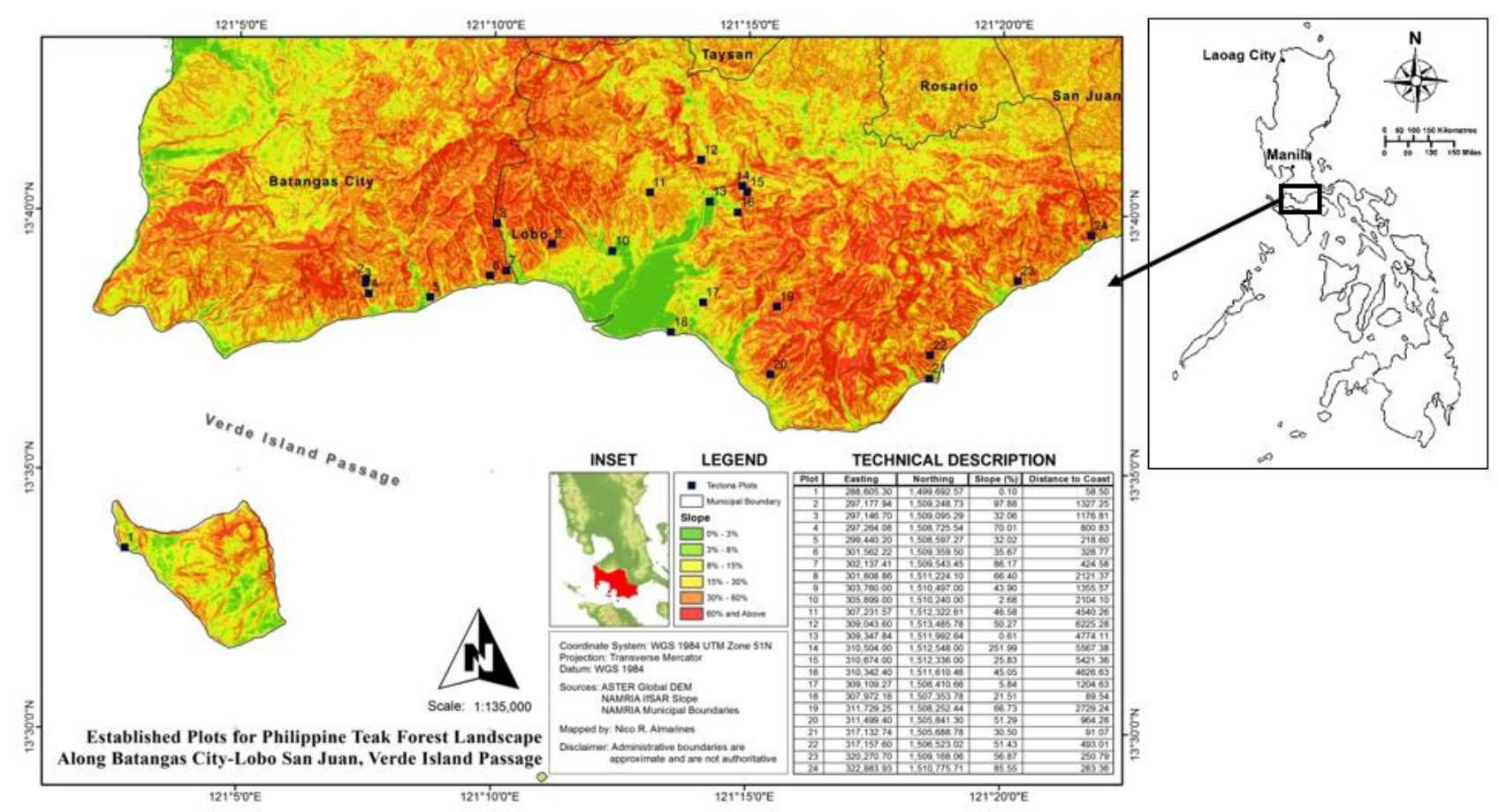

Figure 1. The Philippine teak forest landscape along the Verde Island Passage, Batangas Luzon, Philippines. The study plots were shown as small 1-24 black squares from an island to coastal-mainland of Batangas Province, Philippines 


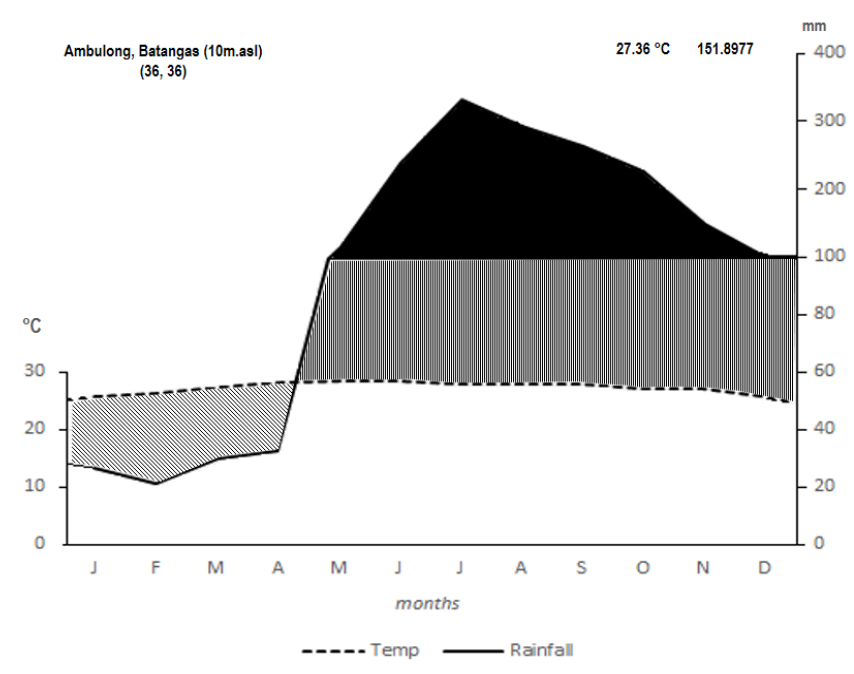

Figure 2. The 36-Year (1980-2016) climogram showing the monthly average precipitation and temperature for Batangas Province, Philippines (Data retrieved from Synoptic Station Records: Ambulong, Batangas. Philippine Atmospheric, Geophysical and Astronomical Services Administration (PAGASA), Diliman, Quezon City, Philippines)

In each plot, the diameter at breast height (DBH) of trees (at least $\geq 10 \mathrm{~cm}$ ) was measured with a diameter tape at $1.3 \mathrm{~m}$ from the ground while heights were estimated visually following Erenso et al. (2014). Crown dimensions were measured by a meter tape following Almazol and Quintana (2009). Altitudes and coordinates of all study plots were taken using a Garmin 76Csx Global Positioning System (GPS) receiver.

Woody plants were identified with the help of local botanists and verified with photographs of plants from the field and herbarium vouchers lodged at the Batangas State University Herbarium (BatStateU-H) and Plant Biology Division Herbarium of the Institute of Biological Sciences, University of the Philippines at Los Baňos (UPLB). Species nomenclature followed the Revised Lexicon of Philippine Trees (Rojo 1999), An Enumeration of Philippine Flowering Plants (Merrill 1923-1926), Flowering Plants and Ferns of Mt. Makiling (Fernando et al. 2004) and Dictionary of Philippine Plant Names (Madulid 2001).

\section{Data analysis}

\section{Cluster analysis}

To identify the plant communities in the forest landscape, the basal area (BA) values of the woody species were subjected to cluster analysis using the unweighted pair group method with arithmetic mean (UPGMA) algorithm and Euclidean distance as the index of similarity among the plots. The PAleontological STatistical (PAST) software (Hammer et al. 2010) was used to run the analysis and generate the cluster dendrogram of the plots. The diagram was used to visualize the representation of the clusters of the vegetation plots as plant communities in the landscape.

\section{Dominance analysis}

The dominant species were identified to further describe each of the plant community that was identified from the cluster analysis. In this study, the relative basal area (RBA) of the woody species was used as a measure of dominance. These were quantitatively identified using the of Ohsawa (1984):

$$
d=\frac{1}{\mathrm{~N}}\left\{\sum_{\mathrm{i} \in \mathrm{T}}\left(\mathrm{x}_{\mathrm{i}}-\overline{\mathrm{x}}\right)^{2}+\sum_{\mathrm{j} \in \mathrm{U}} \mathrm{x}_{\mathrm{I}}^{2}\right\}
$$

Where:

d : The deviation

$\mathrm{x}_{\mathrm{i}}$ : The actual percent share [in this case, the RBA] of the top species (T), i.e, the top dominant in the onedominant model, or the two top dominants in the twodominant model and so on

$x$ : The ideal percent share based on the aforementioned model

$\mathrm{x}_{\mathrm{j}}$ : The percent share of the remaining species (U)

$\mathrm{N}$ : The total number of species.

Consequently, each plant community (cluster) was named after the dominant and co-dominant tree flora, i.e. species with the highest RBA values. The number of the dominant species that represent the plant communities was based on the formula above.

\section{Proximity analysis for physiographic and anthropogenic factors}

Proximity analysis of the Philippine teak plots to the various physiographic regime such as altitude (m asl.) and distances $(\mathrm{m})$ to or from the streams, coast or shoreline and anthropogenic disturbances (e.g. roads, built-up areas, settlements, farms) was undertaken by an ArcGIS specialist. This computed the approximate straight line distance (measured in meters) between a plot and any spatial object, given a UTM $51 \mathrm{~N}$ projected coordinate system and a WGS 1984 geographic projection. The stream network used for the analysis was topographically derived from NAMRIA's 5m spatial resolution IfSAR DEM, provided that first-order streams have a minimum catchment area of $20,000 \mathrm{~m}^{2}$. The road network is from Open Street Maps, and built-up areas were isolated from the latest available land cover map of NAMRIA. The results of the GIS-based approximate analysis, however, was in some aspects validated with the actual observation in the studied plots, hence there were some data finetunings.

\section{Edaphic environment analysis}

These are the results of laboratory analysis done on basic soil chemical properties such as acidity (pH), moisture content (\%MO), organic matter (\% OM) and organic carbon $(\% \mathrm{OC})$, nitrogen $(\% \mathrm{~N})$, phosphorus $(\mathrm{P}$ $\mathrm{ppm})$, and potassium (K ppm). Soil samples in each plot were collected uniformly following the procedures formulated by PCARR (1980). Soil sampling point $(25 \mathrm{~cm}$ x $25 \mathrm{~cm}$ x $30 \mathrm{~cm}$ pit) was dug using an auger and spade 
from four corners of each plot and 1 from the middle. At least $1 \mathrm{~kg}$ soil slices from these 5 points were mixed thoroughly and cleared with stones, grasses, weeds or other plant debris. Each $1 \mathrm{~kg}$ soil sample was sealed in a plastic bag, labeled and were analyzed at the Regional Soils Testing Laboratory of the Philippine's Department of Agriculture (DA) in Lipa City, Batangas. These quantitative values were identified and used in analyzing the influence of the environment variables (including soil data) on the formation of the plant communities in the landscape.

\section{Canonical correspondence analysis}

To explain the relationship of dominant tree flora in the Philippine teak forest with the habitat environment factors, Canonical Correspondence Analysis (CCA) of Ter Braak (1986) was performed using the statistical software R version 3.4.2 (R Core Team, 2013) with the vegan package (Oksanen et al. 2007). Environmental factors including soil data, altitude, slope and proximity to anthropogenic disturbances were tested (Table 1). These environmental gradients are the basis for visualizing (modelling) and describing the differential habitat preferences (niches) of taxa through an ordination diagram.

\section{RESULTS AND DISCUSSION}

\section{Plant communities of the woody plants in the Philippine teak forest landscape}

The dendrogram generated from cluster analysis of woody species basal area (BA) revealed four plant communities (Table 2, Figure 3 ) named according to their dominant species: (I) pure Tectona philippinensis (33-213 $\mathrm{m}$ asl.), (II) mixed Tectona-Garuga-Terminalia (37-321 m asl.), (III) mixed Celtis-Tectona (53 $\mathrm{m}$ asl.) and (IV) mixed Tamarindus-Xylocarpus (8-209 m asl.) (Figure 4).

Table 1. Environmental variables used in Canonical Correspondence Analysis (CCA)

\begin{tabular}{lll}
\hline Environmental variable & Abbreviation \\
\hline Physiographic & Percent slope & SLP \\
& Proximity to the sea & SEA \\
& Proximity to the river & RIV \\
& Altitude & ALT \\
& & \\
Edaphic & Soil moisture & MO \\
& Organic carbon & OC \\
& Organic matter & OM \\
& pH & pH \\
& Phosphorus & P \\
& Potassium & K \\
Anthropogenic & Proximity to built-up areas/ & SETL \\
& settlement & \\
& Proximity to swidden or farm & FR \\
& Proximity to road & RD \\
\hline
\end{tabular}


Table 2. Tree communities, distribution of the sample plots and observed human disturbances in the Philippine teak forest landscape

\begin{tabular}{|c|c|c|c|c|c|c|c|c|}
\hline Tree communities & $\begin{array}{l}\text { Tree or } \\
\text { woody } \\
\text { species } \\
\text { richness }\end{array}$ & $\begin{array}{c}\text { Altitude } \\
\text { (m asl.) }\end{array}$ & $\begin{array}{l}\text { Slope } \\
(\%)\end{array}$ & $\begin{array}{l}\text { Dominant } \\
\text { trees }\end{array}$ & $\underset{\left(\mathbf{m}^{2}\right)}{\sum \mathbf{B A}}$ & $\begin{array}{c}\text { RBA } \\
(\%)\end{array}$ & $\begin{array}{c}\text { Observed } \\
\text { Anthropogenic } \\
\text { Disturbances } \\
(\text { ADs)* }\end{array}$ & Location \\
\hline $\begin{array}{l}\text { Cluster I } \\
\text { (plots: } 3,4,7,16,17,13 \text {, } \\
20,1,24,22,12 \text { ) }\end{array}$ & 25 & $33-213$ & $0.61-86.17$ & $\begin{array}{l}7 \text { Tectona } \\
\text { philippinensis }\end{array}$ & 748.01 & 72.65 & $\begin{array}{l}\text { SCP, PGL, AT, } \\
\text { FLG, Ro, HS }\end{array}$ & $\begin{array}{l}\text { Inland ridges, } \\
\text { valley, coast }\end{array}$ \\
\hline $\begin{array}{l}\text { Cluster II } \\
\text { (plots: } 6,14,15,8,18, \\
9,10,21,11,19 \text { ) }\end{array}$ & 36 & $37-321$ & $\begin{array}{l}2.68- \\
251.99\end{array}$ & $\begin{array}{l}\text { T. philippinensis } \\
\text { Terminalia polyantha } \\
\text { Garuga floribunda }\end{array}$ & $\begin{array}{l}521.43 \\
395.84 \\
186.71\end{array}$ & $\begin{array}{l}36.43 \\
27.66 \\
13.05\end{array}$ & $\begin{array}{l}\text { SCP, PGL, AT, } \\
\text { FLG, Ro, HS }\end{array}$ & $\begin{array}{l}\text { Inland ridges, } \\
\text { coast }\end{array}$ \\
\hline $\begin{array}{l}\text { Cluster III } \\
\text { (plot: 5) }\end{array}$ & 5 & 53 & 32.02 & $\begin{array}{l}\text { Celtis latifolia } \\
\text { T. philippinensis }\end{array}$ & $\begin{array}{l}26.36 \\
18.18\end{array}$ & $\begin{array}{l}51.51 \\
35.54\end{array}$ & $\begin{array}{l}\text { SCP, PGL, AT, } \\
\text { FLG, Ro, HS }\end{array}$ & Coastal cliff \\
\hline $\begin{array}{l}\text { Cluster IV } \\
\text { (plots: } 2,23 \text { ) }\end{array}$ & 12 & $8-209$ & $\begin{array}{l}56.87- \\
97.88\end{array}$ & $\begin{array}{l}\text { Tamarindus indica } \\
\text { Xylocarpus rumphii }\end{array}$ & $\begin{array}{c}161.42 \\
66.74 \\
\end{array}$ & $\begin{array}{l}52.79 \\
21.83 \\
\end{array}$ & AT, FLG, Ro, HS & $\begin{array}{l}\text { Ridge valley } \\
\text { and ridge coast }\end{array}$ \\
\hline
\end{tabular}

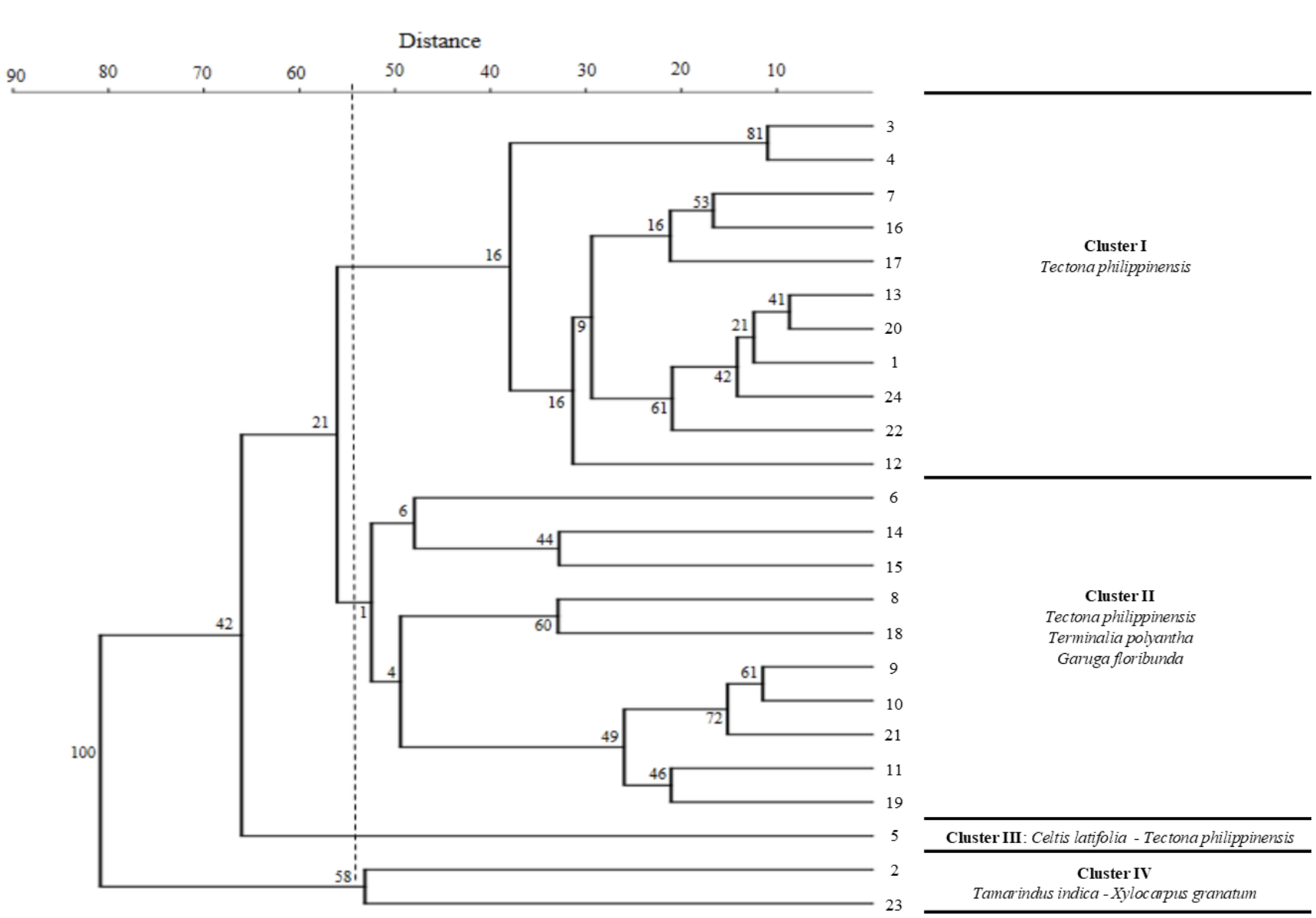

Figure 3. Dendrogram generated from cluster analysis based on woody species basal area (BA) in the Philippine teak forest landscape using the UPGMA algorithm with cophenetic correlation of 0.88 . At a Euclidean distance between 50-60, four clusters were identified with corresponding dominant tree species having the highest relative basal area (RBA). 


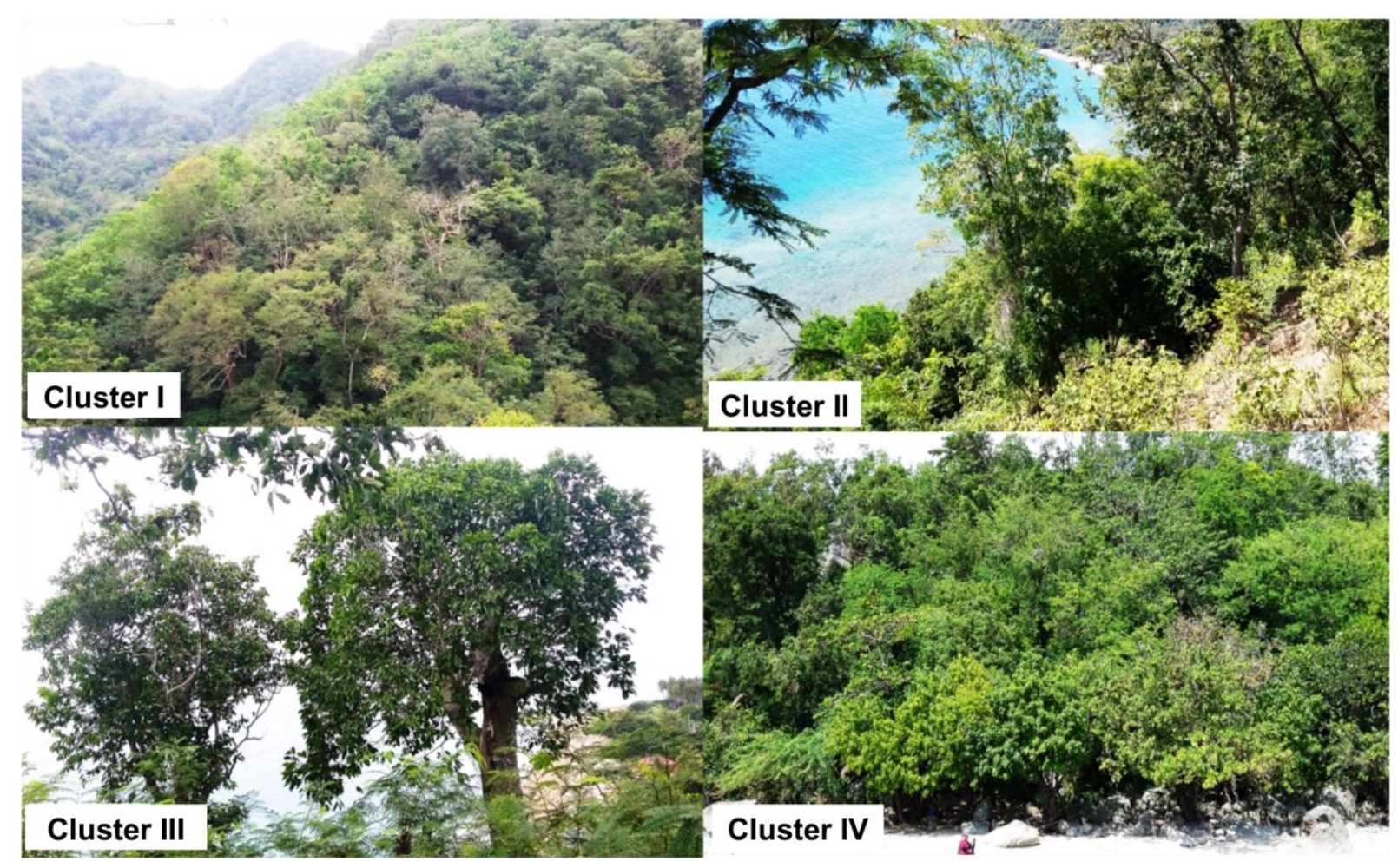

Figure 4. Photographs of four clusters (zones) of woody plants in the Philippine teak forest landscape representing ridge-to-coast habitats

The result of ordination is complementing the cluster analysis which modelled four plant communities (Figure $3)$. On the upper portion of the biplot was Cluster II, associated with edaphic factors such as increasing level of potassium (K), soil moisture (MO) and pH. Cluster III (Plot $5 \mathrm{MC}$ ) was more sensitive to moisture and $\mathrm{pH}$ levels, while Cluster IV (Plots 2 RV and 23 MC) except with phosphorous level was diverged from most of the edaphic vectors and was also influenced by slope gradient (Figure 5 , Figure 6). The lower part of the second axis showed that Zone I (valley and ridge plots) was greatly influenced by physiographic factors such as altitude (ALT) and distance from the coast (SEA).

However, considering the holocoenotic nature of the environment, these seemingly isolating influences of certain edaphic or physiographic factors might also be coupled with other influences such as low to moderate effects of slope (SLP), other edaphic attributes such as level of organic matter (OM), organic carbon (OC) and phosphorous (P); anthropogenic disturbances such as roads (RD), farming (FR) and settlement (SETL) or by combination of all these factors. Interestingly, the sites were ordained generally far from riparian influence (RIV), suggesting that PTF is a formation characteristic of the dry woodland environment along Verde Island Passage.

\section{Discussion}

The communities of woody plants have their own distinct characteristics species. There was the pure natural stand of T. philippinensis in Cluster I while mixed-stand of $T$. philippinensis, Terminalia polyantha and Garuga floribunda in Cluster II. The forest canopy in these zones become typically deciduous during summer and extended drought. Garuga floribunda was a typical tree of the semideciduous forest from 0-900 m altitude in Sierra Madre and Palawan, but in Batangas it was a rare co-dominant with endemic T. philippinensis. The PTF occurs with beach flora such as Celtis latifolia (Cluster III) but overshadowed in terms of dominance by Xylocarpus rumphii and Tamarindus indica (Cluster IV). Though $T$. indica was encountered on the island and mainland beach coast or coastal cliff, it has a very low affinity with the beach forest's $X$. rumphii as the former was more frequent in inland valley and ridges.

The vegetation succession or the dynamic of habitatenvironment interaction can be initiated by the interplay of the following factors: [i] floristic composition of a given landscape, [ii] ability of a given species to reach the habitat, [iii] eco-physiology and morphology of plant life, [iv] the habitat, and [v] the time that has elapsed following a major disturbance (Mueller-Dombois and Ellenberg 2002). The Philippine teak plant communities can be best seen as a consequence of habitat-environment gradient filtering, as well as habitat specialization, as proposed by Oliveira et al. (2014) for the "restinga" forest in the Brazilian coast, where more abundant species in "restinga" forest has niche overlap with other species in at least one habitat. Closely related species tended to occur in different habitats while neighboring trees tended to belong to more distantly related species (Oliveira et al. 2014). This made the structure of the ecological species groups to be associated with a combination of habitat factors such as elevation, soil $\mathrm{pH}$, vegetation type and management disturbance regime and, thus, good indicators (Quimio et al. 2013). 


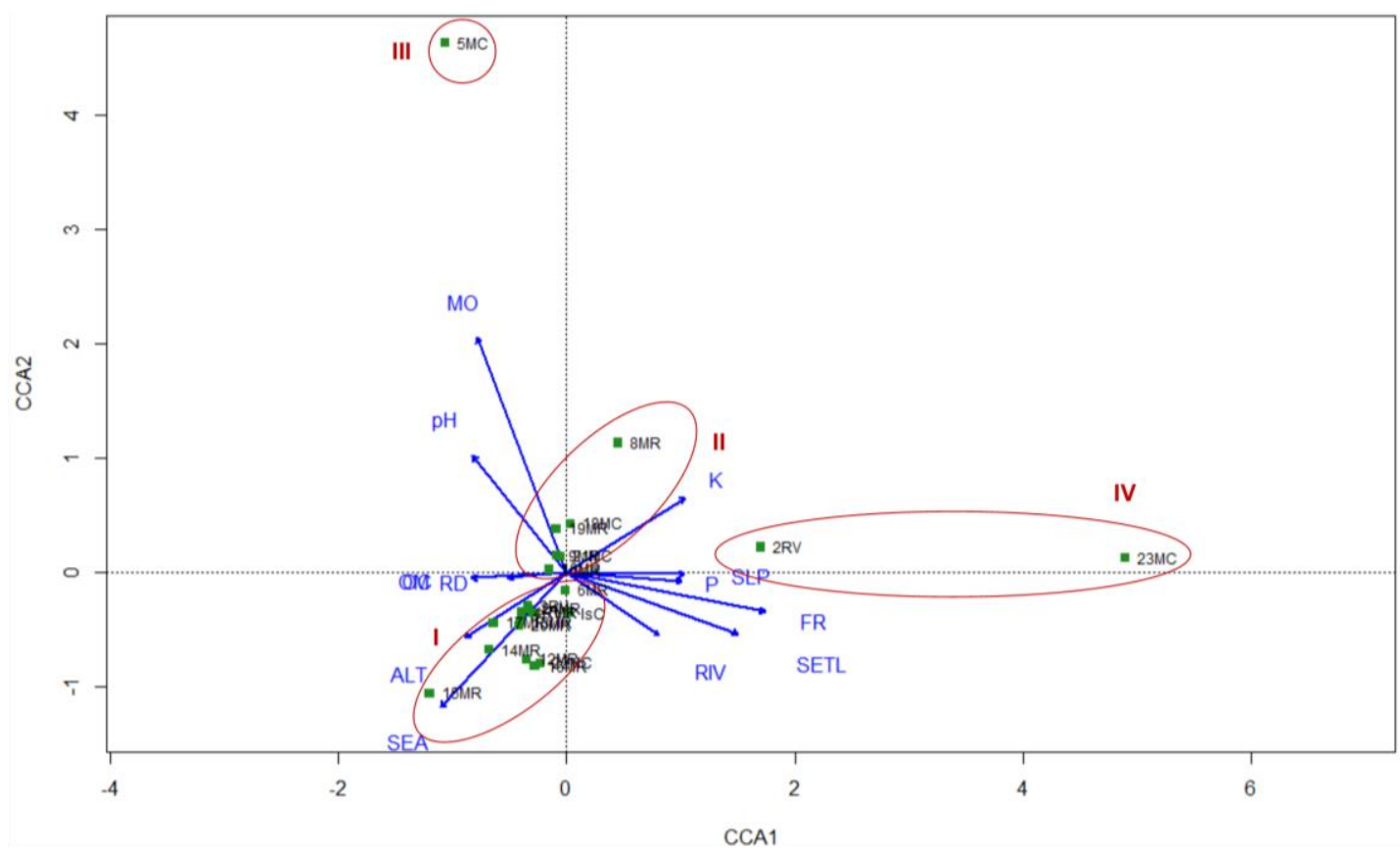

Figure 5. The results of ordination analysis in the studied area over 13 environmental variables using Canonical Correspondence Analysis (CCA) based on relative basal area (RBA) of 47 woody species. The 13 environmental variables were: physiographic-percent slope (SLP), proximity to the sea (SEA) and river (RIV), and altitude (ALT) above the sea; edaphic-levels of soil moisture (MO), organic carbon $(\mathrm{OC})$, organic matter $(\mathrm{OM}), \mathrm{pH}$, phosphorous $(\mathrm{P})$ and potassium $(\mathrm{K})$ and anthropogenic-proximity to built-up areas, settlement (L or SETL), swidden or farm (FR) and road (RD). The objects (plots 1-24, green squares) are representing four vegetation zones across satoyama-satoumi landscape such as mainland ridges (MRs), ridge valleys (RVs), mainland coast (MC) and island coast (IsC). The four clusters of plots are encircled in red

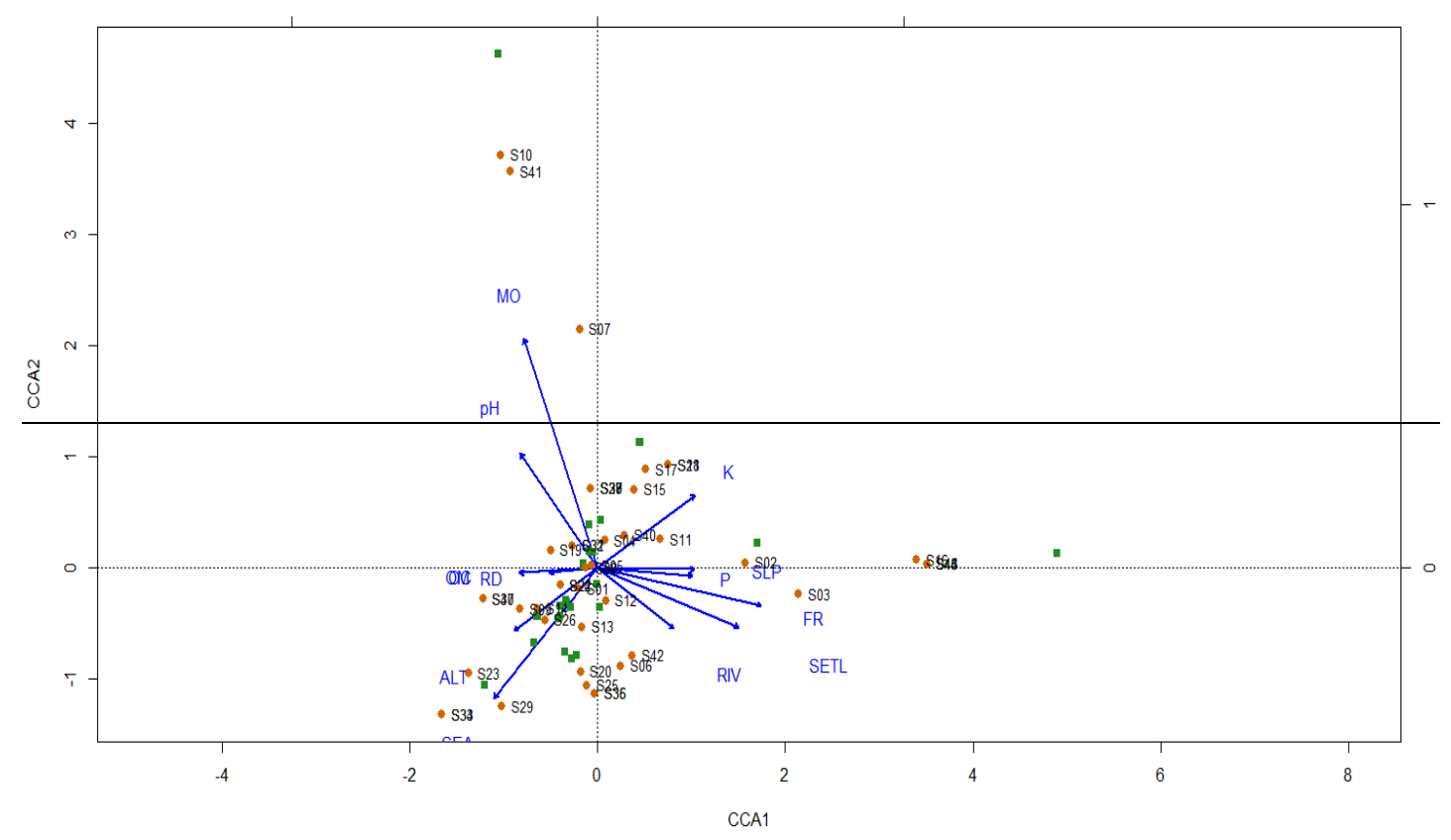

Figure 6. CCA ordination diagram showing the distribution of the woody species in the biplot (orange dots S1 to Sn...). The figure also indicated the 24 sampling sites (green squares, unlabeled) and 13 environmental variables influencing the distribution patterns of the woody species. The $\mathrm{S} n$ are descriptors of 47 woody species under the following genera: Spondias (S1), Wrightia (S2), Garuga (S3), Bauhinia (S4), Tamarindus (S5), Celtis (S6), Capparis (S7), Crateva (S8), Salacia (S9), Terminalia catappa (S10), T. polyantha (S11), Cycas (S12), Diospyros (S13), Macaranga (S14), Hibiscus (S15), Melanolepis (S16), Gliricidia (S17), Scolopia (S18), Cratoxylum (S19), Tectona philippinensis (S20), Vitex (S21), Dehassia (S22), Berrya (S23), Bombax (S24), Colona (S25), Grewia (S26), Pterocymbium (S27), Pterospermum (S28), Sterculia (S29), Thespesia (S30), Memecylon (S31), Xylocarpus (S32), Acacia (S33), Albizia (S34), Leucaena (S35), Ficus sumatrana (S36), F. ulmifolia (S37), F. variegata (S38), Antidesma (S39), Canthium (S40), Guettarda (S41), Mussaenda (S42), Tarrena (S43), Murraya (S44), Dimocarpus (S45), Dodonaea (S46) and Harpaullia (S47). 


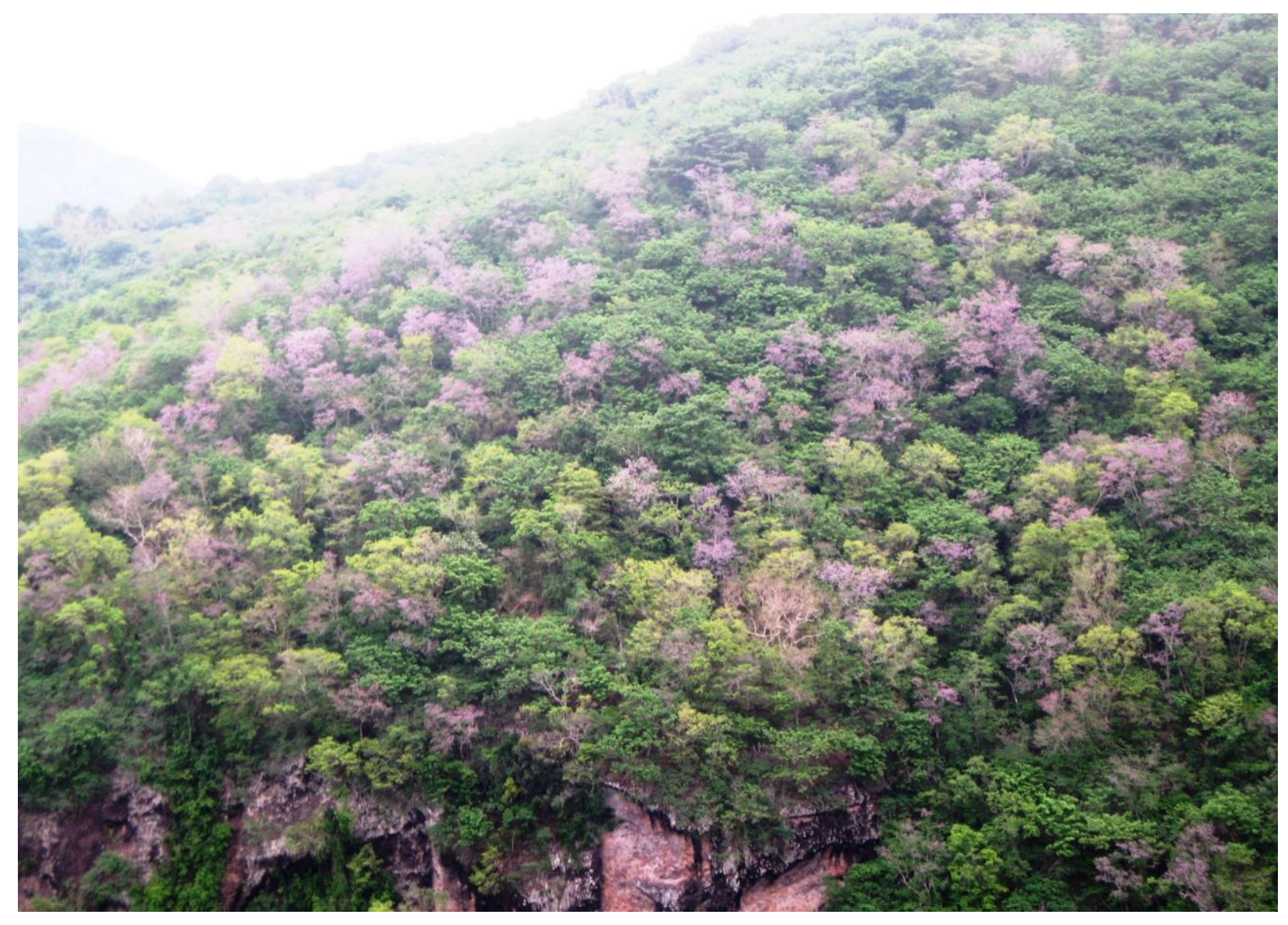

Figure 7. The Philippines teak forest (PTF) in inland ridge. The lilac canopies are all individual Tectona philippinensis during mass flowering on the onset of southwest monsoon in Batangas Province, Philippines

Edaphic and physiographic factors displayed influence on the formation of plant communities and species distribution patterns. Available edaphic data analysis further revealed that PTF occurred in slightly acidic to acidic soils ( $\mathrm{pH} 5.73)$; low in moisture $(11.88 \%)$ but still has an adequate organic matter $(6.08 \%)$; medium organic carbon content $(3.54 \%)$, medium amount of phosphorus $(8.37 \mathrm{ppm})$ and extremely high potassium content (360.5ppm). Given such data-based analysis, the PTF can be seen improving soil quality or evolved by sets of the valuable edaphic environment (forest-soil interaction), hence the dominant $T$. philippinensis can be considered among the edaphic-endemic species of the Philippines. The Philippine teak forests occurred along coastal hills, littoral cliffs and inland limestone ridges with shallow sedimentary rock formation known as Mt. Santiago Limestone developed during the Pliocene and Pleistocene period (Madulid and Agoo 1990; Bureau of Soils 1987; Caringal et al. 2015). Generally, limestone substrate have shallow clayey topsoil consisting mainly of porous calcium carbonate and sands (Cox 2010), low in water and nutrient holding capacity and high permeability, slightly acidic to mildly alkaline and moderate to high fertile soils support the Philippine teak forest (Ecosystems Research and Development Bureau 2003; Hernandez et al. 2016). All these, together with other attributes of limestone substrates, make the PTF landscape a very dry one (Whitford 1911). The arid environment of PTF can be also attributed to anomalous macroclimate turning the forest completely deciduous, creating canopy gaps and exposing the landscape to direct sunlight during summer and periodic prolonged droughts (Madulid and Agoo 1990; Caringal and Makahiya 2000; Caringal et al. 2015; Briones et al. 2018). Under these stressful edaphic-climatic conditions, it was found out that $T$. philippinensis had already developed special physio-anatomical features related to persistent adaptation in xeric habitat (Hernandez et al. 2016). Edaphic factors such as moisture availability and nutrients directly influence species niche differentiation and spatial distribution of tropical trees at the local-regional scales (Engelbrecht et al. 2007). The assembly of tropical tree communities at plot scales is largely influenced by soils and habitat factors in the landscapes (John et al. 2006).

As a semi-deciduous secondary forest, PTF depends on the dynamic aspect of physiography as it grows on low relief, slightly dissected limestone hills and abyss with slopes ranging from 18 to $50 \%$ characterized by moderate hazards (Madulid and Agoo 1990). More specifically, available GIS proximity data analysis showed that on the average, the PTF grows inland at low altitude (142 $\mathrm{m}$ asl.) as far as $1.95 \mathrm{~km}$ from the coast; along steep ridges or hilly to mountainous areas $(52.37 \%$ slope $)$ and very far 
$(2.038 \mathrm{~km})$ from major riparian vegetation. The forest formations in the Philippines were classified according to physiographic conditions from sea level up to the highest mountain (DENR-UNEP 1997; Malayang 2001; Pulhin 2002; Fernando et al. 2008). Richardson et al. (1995) stressed that soils and topographic conditions explained well the patterns of distribution and co-existence among plant species.

Pausas and Austin (2001) suggested that studying multidimensional environmental factors can help understand the plant species composition in the landscape. This generalization was particularly important for the PTF as other factors are affecting this threatened biota. In particular, the forest patches are generally far $(1.4 \mathrm{~km})$ from the settlement but near, $129.4 \mathrm{~m}$ to cultivated hilly lands and affected by road expansion $364 \mathrm{~m}$ away. Patches of "kaingin" (swidden), monocrop "ates" plantations as well as grazing extend up from the base of the coastal hills to narrow uplifted valley and inland ridges where there are sparse human settlements and road extensions. In less accessible ridges known by Loboanos as "nasya" (horseback) and "kastilyo" (rocky ridgetop), natural stands of T. philippinensis have straight boles and with medium to large diameter individuals. Here, some rare and singleton species such as Cycas, Diospyros, Murraya, Vandas, geophytes, and epiphytes thrive well. But in more disturbed sites such as frequently grazed valley and coastal hills cleared for farming, settlement, and dissected by road construction, T. philippinensis exhibits slashed and stunted growth, multi-stemmed and intermixed with shrubs and undershrubs of the genus Chromolaena, Hyptis, Lantana, and Sida.

This study identified four plant community types along the Philippine teak forest landscape at Verde Island Passage, Batangas, Philippines. The formation of the plant communities does not only reveal the dominance of $T$. philippinensis on-site (Clusters I); it also displayed the coexistence and/or co-dominance of other plant species, as in the case of the other clusters identified (II, III and IV) from the cluster and dominance analyses.

The PTF has its ecological niche among the classified Philippine forest formations. Within the broad and yet regionally important tropical forests, environmental factors such as elevation and soil type have determined the corresponding differences in forest structure and dominant species. Though climatic factors like rainfall also helped essentially the unique plant diversity, 'geodiversity' (soil type and elevation) was greatly recognized for the existence of different forest formations in the tropics such as the tropical dry forest and semi-evergreen forest (Thomas and Baltzer, 2002).

For future studies, it is also recommended to consider conducting studies on the vegetation of PTF on other areas along the Verde Island Passage, particularly in the areas of Northwest Island and other coastal municipalities (Mabini, Tingloy, and Nasugbu) in Batangas. Moreover, GIS mapping of this forest type will also be helpful for the landuse zoning and development planning, so that the conservation and management efforts for the Philippine teak will be integrated into the local and national government initiatives.

\section{ACKNOWLEDGEMENTS}

This study was made possible by the Accelerated Science and Technology Human Resource Development Program - National Science Consortium (ASTHRDPNSC) of the Department of Science and Technology (DOST) through the Graduate School and School of Environmental Science and Management, University of the Philippines Los Baňos (GS/SESAM, UPLB), Philippines. The portion of botanical herbarium collections in Lobo, Batangas was also covered by the research fund of Batangas State University (BatStateU), Philippines.

\section{REFERENCES}

Agoo EMG, Oyong GG. 2008. Assessment of genetic diversity in Tectona philippinensis Benth. \& Hook.f, (Verbenaceae) inferred from TRNL intron sequences. Philipp Sci 45: 80-89.

Almazol AE, Quintana SB. 2009. Tree species composition and physiognomy of Kinabuhayan River riparian zones, Mt. BanahawSan Cristobal Protected Landscape. Sylvatrop Tech J Philipp Ecosyst Nat Res 19 (1\&2): 29-56.

Aragones EGJr. 1991. Vegetation-soil pattern along altitudinal gradient in the western slopes of Mt. Banahaw, Luzon, Philippines: I. The forest communities and changes in forest composition with altitude. Sylvatrop Tech J Philipp Ecosyst Nat Res 1 (1): 15-45.

Baguinon NT. 2000. ENRM 202: Forest and Terrestrial Ecosystems. University of the Philippines Open University, Los Ban̆os Laguna, Philippines.

Bureau of Mines and Geo-Sciences-Mindoro Resources Limited Gold Philippines Inc. 1981. Batangas Regional Geology. Philippines.

Bureau of Soils. 1987. Land Resources Evaluation Project: Physical Land Resources, Province of Batangas (1). Bureau of Soils Publ, Manila, Philippines.

Belonias BS, Aguilar NO. 2004. Altitudinal zonation of dicots on Mt. Pangasugan, Leyte Island, Philippines. J Env Sci Manag 7 (2): 47-66.

Briones RU, Tadiosa ER, Manila AC. 2017. Threats on the natural stand of Philippine Teak along Verde Island Passage Marine Corridor (VIPMC), Southern Luzon, Philippines. J Env Sci Manag 20 (2): 5467.

Buot IE Jr. 2007. Vegetation zonation of Mt. Akiki, Cordillera Mountain Range, Benguet Province, Philippines. Asia Life Sci 16 (1): 53-70.

Buot IE Jr. 2008. Vertical distribution and zonation pattern of woody vegetation on the northwestern slope of Mt. Mayon, Philippines. Asia Life Sci 17 (2): 189-205

Buot IE Jr, Okitsu S. 1998. Vertical distribution and structure of the tree vegetation in the montane forest of Mt. Pulag, Cordillera mountain range, the highest mountain in Luzon Is, Philippines. J Veg Sci 15: 19-32.

Buot IE Jr, Osumi K. 2011. Land use type pattern and woody species composition near human disturbed landscapes on Mount Makiling, Luzon Island. Am J Environ Sci 7 (4): 306-315.

Bureau of Soils. 1987. Land Resources Evaluation Project: Physical Land Resources, Province of Batangas. Vol. 1, Bureau of Soils Publ, Manila.

Cadiz R. 1986. Overview of the Philippine forests; Proceeding of the Field Training Seminar on Forest Habitat Matching, 12-28 January 1986. Sakaerat, [Thailand].

Caringal AM. 2007. Biodiversity assessment in Lobo-San Juan mountains. Mountain Forum Bull 7 (1): 7-8.

Caringal AM, Makahiya, A.M. 2000. Field study of Philippine teak (Tectona philippinensis Benth. \& Hook. f.) in Lobo, Batangas: Rediscovering a century-old botanical treasure and global heritage. PBMIT Res J 4 (2): 15-29.

Caringal AM, Buot IE Jr, Aragones EG Jr. 2015. Population and reproductive phenology of the Philippine teak (Tectona philippinensis Benth. \& Hook. f.) in Lobo coast of Verde Island Passage, Batangas, Philippines. Philip Agric Sci 98 (3): 312-322. 
Comprehensive Land Use Plan (2012-2022) of Lobo Batangas. 2012. The Local Government of Lobo, Batangas. Municipal Planning and Development Office. Lobo, Batangas. [Philippines].

Cox DM. 2010. Mineral Resources Estimate Upgrade on the Kay Tanda Project, Luzon, Philippines (NI 43-101 Report). Mindoro Resources Limited. Edmonton, Alberta, Canada.

De Oliveira AA, Vicentini A, Chave J, Castanho CDT, Davies SJ, Martini AMZ, Lima RAF, Ribeiro RR, Iribar A, Souza VC. 2014. Habita specialization and phylogenetic structure of tree species in a coastal Brazilian white-sand forest. J Plant Ecol 7 (2): 134-144.

Department of Environment and Natural Resources-United Nations Environment Program. 1997. Philippine Biodiversity: An Assessment and Action Plan. Bookmark. Inc, Manila.

Ecosystems Research and Development Bureau. 2003. Resource Assessment, Economic Valuation and Identification of Rehabilitation Strategies and Alternative Livelihood Options in Areas Within and Surrounding the Batangas Bay, Philippines, Focus on Lobo Watershed (A Terminal Report of a funded research project by the ASEAN Regional Center for Biodiversity Conservation and European Union, ERDB-DENR, College Laguna 4031.138p.

Engelbrecht BM, Comita LS, Kursar TA, Tyree MT, Turner BL, S.P. Hubbell SP. 2007. Drought sensitivity shapes species distribution patterns in tropical forests. Nature 20447 (7140): 80-82.

Erenso F, Maryo M, Abebe W. 2014. Floristic composition, diversity and vegetation structure of woody plant communities in Boda dry evergreen Montane Forest, West Showa, Ethiopia. Intl J Biodiv Conserv 6 (5): 382-391.

Fernando ES. 1988. Diversity of the flora in the Philippine forest ecosystems; Proceeding of the Technical Workshop on Philippine Biological Diversity sponsored by Haribon Foundation and the International Institute for Environment and Development, 01-02 March 1988, PCIED Hostel, University of the Philippines at Diliman, Quezon City. [Philippines].

Fernando ES, Sun BY, Suh MH, Kong HY, Koh KH. 2004. Flowering plants and ferns of Mt. Makiling. Seoul National University, Korea.

Fernando ES, Suh MH, Lee J, Lee DK. 2008. Forest formations of the Philippines. Seoul National University, Korea.

Hammer O, Harper DAT, Ryan PD. 2010. Paleontological Statistics (PAST) package for education and data analysis Software v2.10. www. folk.uio.no/ohammer/past.

Heng RKJ, Mang NG, Huat OK, Sait M, Sam S, Empin GB, Rajanoran T, Sinus CR. 2017. Tree diversity at Payeh Maga Montane Forest, Sarawak, Borneo. J Trop Biol Conserv 14: 125-150.

Hernandez JO, Malabrigo PL, Quimado MO Jr, Maldia LSJ, Fernando ES 2016. Xerophytic characteristics of Tectona philippinensis Benth. \& Hook.f. Philip J Sci 145 (3): 259-269.

John RJ, Dalling K, Harms J, Yavitt R, Stallard M, Mirabello S, Hubbell R, Valencia H, Navarrete M, Vallejo, Foster R. 2006. Soil Nutrients influence spatial distributions of tropical tree species. Proc Natl Acad Sci USA 104 (3): 864-869.

Kent M, Coker P. 1992. Vegetation Description and Analysis: A practical Approach. CRC Press, Boca Raton, Ann Arbor and Belhaven Press, London.

Madulid DA, Agoo EMG. 1990. Conservation status of Tectona philippinensis Benth. \& Hook. f, a threatened plant. Acta Manila 38 41-56.

Madulid DA 2001. A Dictionary of Philippine Plant Names. The Bookmark, Inc, Manila.

Madulid DA. 1994. Plant diversity in the Philippines. In: Proceedings of the International Symposium on Biodiversity and Terrestrial Ecosystems. 17-20 April 1994.

Madulid DA, Agoo EMG, Caringal AM. 2008. Tectona philippinensis. The IUCN Red List of Threatened Species. Version 2014.3. www.iucnredlist.org.

Malayang BS III. 2001. Environmental governance and forest policy in the Philippines: why the continuing debate over sustainable fores management. Paper presented to the Forestry Development Center, $23^{\text {rd }}$ Foundation Day, College of Forestry and Natural Resources, University of the Philippines Los Banos, College, Laguna, 27 June 2001. [Philippine].

Merrill ED. 1923. Enumeration of Philippine Flowering Plants. Bureau of Printing, Manila

Merrill ED. 1923-1926. An Enumeration of Philippine Flowering Plants (1-4). Bureau of Printing, Manila.
Mindoro Resources Limited. 2004. Annual Report. Mindoro Resources Limited, Philippines.

Mueller-Dombois D, Ellenberg H. 2002. Aims and Methods of Vegetation Ecology. Wiley, New York.

Mueller-Dombois D, Ellenberg H. 1974. Aims and Methods of Vegetation Ecology. John Wiley and Sons, Inc, Canada.

Newbery D McC, Kennedy DN, Petol GH, Madani, Ridsdale CE.1999. Primary forest dynamics in lowland dipterocarp forest at Danum Valley, Sabah, Malaysia and the role of understorey. Phil Trans R Soc London B. 354: 1763-1782.

Newbery D McC, Campbell EJF, Lee YF, Ridsdale CE, Still MJ.1992. Primary lowland dipterocarp forest at Danum Valley, Sabah, Malaysia: structure, relative abundance and family composition. Phil Trans R Soc London B 335: 341-356.

Nguyen TV, Mitlöhner R, Bich NV. 2015. Environmental factors affecting abundance and presence of tree species in a tropical lowland limestone and non-limestone forest in Ben En National Park, Vietnam. J For Environ Sci 31 (3): 177-191.

Ohsawa M. 1984. Differentiation of vegetation zones and species strategies in the subalpine region of Mt. Fuji. Plant Ecol 57: 15-52.

Oksanen J, Kindt R, Legendre P, O’Hara B, Stevens MHH, Oksanen, MJ, Suggests M. 2007. The vegan package. Commun Ecol Package 10: 631-637

Oliveira AAD, Alberto V, Jerome C, Castanho CDT, Davies SJ, Martini AMZ, Lima RAF, Ribeiro RR, Iribar A, Souza VC. 2014. Habitat specialization and phylogenetic structure of tree species in a coastal Brazilian white-sand forest. J Plant Ecol 7 (2): 134-144.

Pausas JG, Austin MP. 2001. Patterns of plant species richness in relation to different environment: An appraisal. J Veg Sci 12: 153-166.

Pulhin JM. 2002. Trends in forest policy in the Philippines. Policy Trend Rep 2002: 29-41.

Quimio JM, Vergara KJS, Capon RS Jr. 2013. Expression of dominance as influenced by soil fertility cylindrica-Saccharum spontaneum vegetation formation. Sylvatrop Tech J Philipp Ecosyst Nat Res 23 (1\&2): 131-148

R Core Team (2013). R: A language and environment for statistical computing. R Foundation for Statistical Computing, Vienna, Austria. URL http: //www.R-project.org/.

Richardson DM, Cowling RM, Lamont BB, van Hensbergen HJ. 1995 Coexistence of Banksia species in South-western Australia: The role of regional and local processes. J Veg Sci 6: 329-342.

Rojo JP. 1999. Revised Lexicon of Philippine Trees. Forest Products Research and Development Institute. Department of Science and Technology. College Laguna, Philippines.

Sopsop LB and Buot IE Jr. 2013. The forest types of Aborlan Guba System, Palawan Island, Philippines. IAMURE Intl J Ecol Conserv 7: 88-104.

Tan BC, Rojo JP. 1988. Floristic inventory of the Philippine tropical rain forests. In: Campbell DG, Hammond D (eds). Floristic Inventory of Tropical Countries. New York, USA.

Ter Braak CJF. 1986. Canonical correspondence analysis: a new eigenvector technique for multivariate direct gradient analysis. Ecology 67: 1167-1179.

Thomas SC, Baltzer JL. 2002. Tropical forests. In: Encyclopedia of Life Sciences. Macmillan Reference Ltd, London, UK.

Van YT, Cochard R. 2017. Tree species diversity and utilities in a contracting lowland hillside rainforest fragment in Central Vietnam. For Ecosyst 4 (1): 9

Villanueva ELC, Buot IE Jr. 2018. Vegetation analysis along the altitudinal gradient of Mt. Ilong, Halcon Range, Mindoro Island, Philippines. Biodiversitas 19 (6): 2163-2174.

Whittaker RH. 1965. Dominance and diversity in land plant communities. Science 147: 250-260.

Whittaker RH. 1960. Vegetation of the Siskiyou Mountains. Ecol Monogr 30: $279-338$.

Whitford HN. 1909. Studies in the vegetation of Philippines, I. (Dipterocarp forests). Philipp J Sci 4 (6): 699-725.

Whitford HN 1911. The Forests of the Philippines. I. Philipp Bureau For Bull 19 (1): 1-94

Whitmore TC 1975. Tropical Rain Forest of the Far East. Clarendon Press, Oxford.

Whitmore TC. 1984. Tropical Rain Forests of the Far East. 2nd ed. Oxford University Press, Oxford.

Whitmore TC.1998. An Introduction to Tropical Rain Forests, 2nd ed. Oxford University Press, Oxford. 